\title{
28 Resarach Square of \\ Prevalent Practices of Solid Waste Management in the Girls Hostels
}

Ekta Kapri ( $\nabla$ etikaprirai@gmail.com )

Chaudhary Charan Singh Haryana Agricultural University https://orcid.org/0000-0002-0755-1716

Manju Mehta

Chaudhary Charan Singh Haryana Agricultural University

Sudesh Gandhi

Chaudhary Charan Singh Haryana Agricultural University

Research

Keywords: Waste management, waste generation, waste collection, non biodegradable

Posted Date: June 16th, 2021

DOI: https://doi.org/10.21203/rs.3.rs-595516/v1

License: () (1) This work is licensed under a Creative Commons Attribution 4.0 International License. Read Full License 


\section{Abstract}

Waste is generated on daily basis through different activities of human beings, which leads to pollution of the environment, which may have serious implications on the health of the individual. Waste generation is also a big problem in schools and universities. To keep that problem in mind study has been conducted on the campus of CCSHAU, Hisar; with the objective to study the type and volume of waste generated in the girl's hostels. The study estimated the daily waste generation from girl's hostels and found waste generation rate was high but the waste collection rate was very low because of the improper ratio between the total number of students and sanitary worker. The waste management system in the university girl's hostels requires not only an estimation of the solid waste but also an understanding of the students' habits and behaviour towards managing solid waste.

\section{Introduction}

With the development of human race around the globe, rigorous changes have come in our everyday activity like education, recreation, travelling, feeding, clothing and with all of these activity we are generating lots of wastes in different form such as solid, liquid, or gas and each have different methods of disposal and management (Arora and Agarwal,2011; Coker, etal.2016). According to the report by World Bank (2019) in 2016, the worlds' cities generated 2.01 billion tonnes of solid waste, amounting to a footprint of 0.74 kilograms per person per day. Waste management can be deals with any form whether it was industrial, biological, or household where it may be harmful to human health. Municipal solid waste management practices deal with large portion of different form of waste (Environment Glossary, 2016; Cheremisinoff, 2003). Waste management practices are also a big problem of the schools and universities. Inside the hostels of schools and universities bio degradable and non biodegradable waste is generated in massive amount and this waste impacts the health of college students and their academic performance (Davidson, 2011). Due to the large number of students lot of waste generated in the hostels and no proper management of the waste generation causes dirtiness in the hostel and this might be major concern of the student's health (Earthwatch, 2007). It is the extensively generic fact that many students depart their hostel room without taking care of it. The hostel sanitation practices directly affects on the living and learning condition student's and also affects the critical thinking, intellectual development and aesthetic appreciation of students (Burnt 1995). Some student having apathetic behaviour towards their hostel surroundings, this contributes to the poor hostel sanitation practices (Ikelegbe and Ogeah, 2007). Environmental knowledge and attitude of college and school students appears to be important as their point of view which plays an important role in providing solution to future environmental problems (Ehrampoush and Moghadam, 2005). These wastes products create serious problems for the municipalities and its safe disposal is becoming a serious environmental problem to our ecology and life supporting systems.

\section{Methodology}

Study has been conducted in the campus of CCSHAU, Hisar. For this study the all girl's hostels (Godavari (H1), International Girls Hostel (H2), Narmada (H3), Gangotri Old Wing (H4), Gangotri New Wing (H5), Gangotri Additional Wing (H6), and Women Scholar (H7)) was purposely selected.

Key information was taken from following methods:

1) Hostel prefects and hostel managers, interactions with waste handlers, mess workers, and 
2) Personal field investigation, observation and, measurement.

Aim of the study was to estimate the daily waste generation and waste collection rate from girl's hostels and the current management practices. A weighing balance machine capacity up to $100 \mathrm{~kg}$ was used for the measurement of wastes.

\section{Waste analysis:}

To determine the per capita waste generation and waste collection rate the following procedures were followed:

\section{Waste generation rate $\left(\mathrm{W}_{\mathrm{G}}\right)$ :}

Solid waste generation rates estimate the amount of waste created by residences or businesses over a certain amount of time (day, year, etc.). Waste generation includes all materials discarded, whether or not they are later recycled or disposed in a landfill (CalRecycle, 2019)

- Determination of the weight of solid waste (w)

- Numbers of students who contributed to the waste generation.

- Waste generation rate

$$
\left(\mathrm{W}_{\mathrm{G}}\right)=\frac{\mathrm{wt}(\mathrm{kg})}{\text { no.of students } \mathrm{X} \text { day }}(\mathrm{kg} / \text { capita } / \text { day })
$$
2016)

\section{Waste collection rate}

Waste collection is the collection of solid waste from point of production to the point of treatment or disposal.

This will produce the waste composition according to the weight. The waste collection rate per students in the studied hostel block also had been determined.

Total waste weighed $(\mathrm{kg})$

Waste collection rate $=$ No.of sample (bin) (Ishak, Mahayuddin, and Mohamed, 2013)

\section{Results}

\section{Type of waste generated in all the girls hostels}

Generally, waste could be liquid or solid waste. Both of them could be hazardous. Liquid and solid waste types can also be grouped into organic, re-usable and recyclable waste.

Biodegradable waste is waste that can be broken down by natural processes. Typically, biodegradable waste is matter derived from plants and animals and other organisms, such as paper, food waste, plant-based plastics, and grass clippings. 
Non-biodegradable waste is waste that cannot be broken down through natural processes. These materials include items such as plastic bags, synthetic materials, plastic bottles, electronic items, and aluminium cans. Biodegradable and non biodegradable waste is generating from the hostels is categorised in following:

\section{Table 1: Biodegradable and Non biodegradable waste}

\begin{tabular}{|ll|}
\hline Biodegradable waste & Non biodegradable waste \\
\hline Paper and paper packing materials & Plastic waste, bottles \& plastic packing materials, plastic bags \\
\hline Cardboard, Carton, & Glass, Bulb \\
\hline Cloth waste & Sanitary napkins, wrappers \\
\hline Junk food waste & Rubber, Leather \\
\hline Fruits waste, dry fruit waste, tree leaves & Metal \\
\hline Kitchen waste & Expired Medicine \\
\hline Sand/dust & Electronic Waste \\
\hline Liquid waste & Cosmetic product waste \\
\hline
\end{tabular}

In the hostels both types of waste (biodegradable and non biodegradable) was generate but some waste were generated frequently and some were occasionally. Cloth, plastic bottles, plastic bag waste generate once in a week; rubber, glass, leather waste were generated once in a month where as paper waste, cardboard, food waste, kitchen waste, liquid waste, fruit waste, poly bags, sanitary napkins generated daily in measurable amount. Plastic waste were generated in huge amount daily in various form like, bottles, milk pouches, shampoo pouches, snacks packets, etc. Sanitary napkins were major non biodegradable waste generated from the all girl's hostels.

\section{Volume of waste generated in the hostels}

Large amount of waste generated from all the girls' hostels in the university. Both biodegradable and non biodegradable waste generated. There are following table shows the volume of waste generated in the girls hostels.

\section{Table 2.1: Hostel H1}




\begin{tabular}{|c|c|c|c|c|c|c|c|}
\hline \multirow[t]{2}{*}{ Floors } & \multirow{2}{*}{$\begin{array}{l}\text { Volume } \\
\text { of } \\
\text { dustbin }\end{array}$} & \multicolumn{3}{|l|}{ A block } & \multicolumn{3}{|l|}{ B block } \\
\hline & & $\begin{array}{l}\text { No. of } \\
\text { dustbins }\end{array}$ & $\begin{array}{l}\text { No. of } \\
\text { students }\end{array}$ & $\begin{array}{l}\text { Volume of waste } \\
\text { generate(kg/day) }\end{array}$ & $\begin{array}{l}\text { No. of } \\
\text { students }\end{array}$ & $\begin{array}{l}\text { No. of } \\
\text { dustbins }\end{array}$ & $\begin{array}{l}\text { Volume of waste } \\
\text { generate(kg/day) }\end{array}$ \\
\hline Ground & $15 \mathrm{~kg}$ & 4 & 23 & $10 \mathrm{~kg}$ & 18 & 1 & $7 \mathrm{~kg}$ \\
\hline$\left.\right|^{\text {st }}$ & $15 \mathrm{~kg}$ & 2 & 18 & $7 \mathrm{~kg}$ & 18 & 1 & $7 \mathrm{~kg}$ \\
\hline II nd & $15 \mathrm{~kg}$ & 2 & 18 & $6 \mathrm{~kg}$ & 18 & 1 & $6 \mathrm{~kg}$ \\
\hline\|\|$^{r d}$ & $15 \mathrm{~kg}$ & 2 & 22 & $9 \mathrm{~kg}$ & 18 & 1 & $5 \mathrm{~kg}$ \\
\hline Total & $60 \mathrm{~kg}$ & 10 & 81 & $32 \mathrm{~kg}$ & 72 & 4 & $25 \mathrm{~kg}$ \\
\hline Mess & $15 \mathrm{~kg}$ & 2 & & $18 \mathrm{~kg}$ & & & \\
\hline
\end{tabular}

Table 2.1 showed that in $\mathrm{H} 1$ hostel there were two blocks, $\mathrm{A}$ and $\mathrm{B}$. In Block $\mathrm{A}$ there were total 81 students and in Block B there were 72 students. In Block A, total waste generation was $32 \mathrm{~kg} /$ day and in Block B, total waste generation was $25 \mathrm{~kg} /$ day and $18 \mathrm{~kg}$ of waste generated from mess. Total waste generation from entire hostel was $75 \mathrm{~kg} /$ day

\section{Table 2.2: Hostel H2}

\begin{tabular}{|lllll|}
\hline Floors & Volume of dustbin & No. of students & No. of dustbins & Volume of waste(kg/day) \\
\hline Ground & $15 \mathrm{~kg}$ & 9 & 2 & $2 \mathrm{~kg}$ \\
\hline I st & $15 \mathrm{~kg}$ & 14 & 2 & $4 \mathrm{~kg}$ \\
\hline II nd & $15 \mathrm{~kg}$ & 16 & 2 & $4 \mathrm{~kg}$ \\
\hline Total & $\mathbf{4 ~ k g}$ & 29 & 6 & $10 \mathrm{~kg}$ \\
\hline Mess & $8 \mathrm{~kg}$ & & 1 & $8 \mathrm{~kg}$ \\
\hline
\end{tabular}

Table2.2 showed that in $\mathrm{H} 2$ Hostel there were total 29 students and total waste generated in one day was $10 \mathrm{~kg}$ where $2 \mathrm{~kg}$ from ground floor, $4 \mathrm{~kg}$ from first and second floor and $8 \mathrm{~kg}$ from the mess. So total waste generated from the hostel was $18 \mathrm{~kg} /$ day.

Table 2.3: Hostel H3 


\begin{tabular}{|lllll|}
\hline Floors & Volume of dustbin & No. of students & No. of dustbins & Volume of waste(kg/day) \\
\hline Ground & 15 & 23 & 3 & $7 \mathrm{~kg}$ \\
\hline I st & 15 & 40 & 3 & $15 \mathrm{~kg}$ \\
\hline II nd & 15 & 60 & 3 & $20 \mathrm{~kg}$ \\
\hline Total & $\mathbf{4 5} \mathbf{~ k g}$ & $\mathbf{1 2 3}$ & $\mathbf{9}$ & $\mathbf{4 2 ~ k g}$ \\
\hline Mess & 15 & & 2 & $12 \mathrm{~kg}$ \\
\hline
\end{tabular}

Table 2.3 revealed that in $\mathrm{H} 3$ Hostel, in each floor there were three dustbins of $15 \mathrm{~kg}$ and 123 students generated $42 \mathrm{~kg}$ waste per day and $12 \mathrm{~kg}$ waste generated from the mess. Total $54 \mathrm{~kg}$ waste generated from the entire hostel per day.

\section{Table 2.4: Hostel H4}

\begin{tabular}{|lllll|}
\hline Floors & Volume of dustbin & No. of students & No. of dustbins & Volume of waste(kg/day) \\
\hline Ground & $15 \mathrm{~kg}$ & 62 & 8 & $20 \mathrm{~kg}$ \\
\hline I st & $15 \mathrm{~kg}$ & 49 & 3 & $15 \mathrm{~kg}$ \\
\hline II nd & $15 \mathrm{~kg}$ & 24 & 3 & $9 \mathrm{~kg}$ \\
\hline Total & $45 \mathrm{~kg}$ & $\mathbf{1 3 5}$ & $\mathbf{1 4}$ & $\mathbf{4 4 ~ k g}$ \\
\hline Mess & $15 \mathrm{~kg}$ & & 2 & $15 \mathrm{~kg}$ \\
\hline
\end{tabular}

Table 2.4 estimated that $\mathrm{H} 4$ hostel, maximum waste was generated form ground floor ( $20 \mathrm{~kg} /$ day). Total 135 students generated $44 \mathrm{~kg}$ of waste per day and $15 \mathrm{~kg}$ of waste generated from the mess per day.

\section{Table 2.5: Hostel H5}

\begin{tabular}{|lllll|}
\hline Floors & Volume of dustbin & No. of students & No. of dustbins & Volume of waste(kg/day) \\
\hline Ground & $15 \mathrm{~kg}$ & 63 & 3 & $18 \mathrm{~kg}$ \\
\hline I st & $15 \mathrm{~kg}$ & 46 & 3 & $12 \mathrm{~kg}$ \\
\hline II nd & $15 \mathrm{~kg}$ & $26+21(\mathrm{RL})$ & 3 & $15 \mathrm{~kg}$ \\
\hline Total & $\mathbf{4 5 ~ k g}$ & $\mathbf{1 5 6}$ & $\mathbf{9}$ & $\mathbf{4 5} \mathrm{kg}$ \\
\hline Mess & $15+35 \mathrm{~kg}$ & & $\mathbf{2}$ & $25 \mathrm{~kg}$ \\
\hline Total waste= & $\mathbf{7 0} \mathbf{~ k g} /$ day & & & \\
\hline
\end{tabular}


Table 2.5 depicts that hostel H5, maximum waste generated form ground floor ( $18 \mathrm{~kg} /$ day) followed by second floor ( $15 \mathrm{~kg} /$ day) which also include RL (Residential Lab). Total $45 \mathrm{~kg}$ of waste generated from the floors per day. In the mess there were two types of dustbins, one was $15 \mathrm{~kg}$ and another was $35 \mathrm{~kg}$ and total waste generated from the mess was $25 \mathrm{~kg} /$ day. Total waste generated from the entire hostel was $70 \mathrm{~kg} / \mathrm{day}$.

\section{Table 2.6: Hostel H6}

\begin{tabular}{|lllll|}
\hline Floors & Volume of dustbin & No. of students & No. of dustbins & Volume of waste(kg/day) \\
\hline Ground & $15 \mathrm{~kg}$ & 41 & 1 & $10 \mathrm{~kg}$ \\
\hline I st & $15 \mathrm{~kg}$ & $35+22$ & 1 & $14 \mathrm{~kg}$ \\
\hline II nd & $15 \mathrm{~kg}+10 \mathrm{~kg}$ & 31 & 2 & $7 \mathrm{~kg}$ \\
\hline Total & $\mathbf{5 5 ~ k g}$ & $\mathbf{1 2 9}$ & $\mathbf{4}$ & $\mathbf{3 1 ~ k g}$ \\
\hline Mess & $15 \mathrm{~kg}+35 \mathrm{~kg}$ & & $\mathbf{2}$ & $20 \mathrm{~kg}$ \\
\hline Total waste= $\mathbf{5 1} \mathbf{~ k g} /$ day & & & \\
\hline
\end{tabular}

Table 2.6 depicts that $\mathrm{H} 6$ hostel, maximum waste generated form first floor ( $14 \mathrm{~kg} /$ day) which also include RL (Residential Lab). Total $31 \mathrm{~kg}$ of waste generated from the floors per day. In the mess there were two types of dustbins, one was $15 \mathrm{~kg}$ and another was $35 \mathrm{~kg}$ and total waste generated from the mess was $20 \mathrm{~kg} / \mathrm{day}$. Total waste generated from the entire hostel was $51 \mathrm{~kg} /$ day.

\section{Table 2.7: Hostel H7}

\begin{tabular}{|llll|}
\hline Floors & No. of students & No. of dustbins & Volume of waste(kg/day) \\
\hline I st & 8 & 1 & $10 \mathrm{~kg}$ (garbage window) \\
\cline { 1 - 1 } II $^{\text {nd }}$ & 12 & & \\
\cline { 1 - 1 } III & 10 & & \\
\hline Total & 30 & $10 \mathrm{~kg}$ \\
\hline Mess & $6 \mathrm{~kg}$ & 1 & $6 \mathrm{~kg}$ \\
\hline Total waste= $\mathbf{1 6} \mathrm{kg} /$ day & & \\
\hline
\end{tabular}

Table 2.7 showed that in $\mathrm{H} 7$ hostel, there were total 30 students. Lower first and second floor were professor residence and form third floor to fifth floor. In this hostel there was a garbage window and all the students and staff, dispose their waste in that garbage window. Total estimated waste generated from the hostel was $10 \mathrm{~kg}$ per day (excluding first and second floor residence) and $6 \mathrm{~kg}$ of waste generated from the mess per day.

Table 3: Total number of students and sanitary workers in the hostels 


\begin{tabular}{|llllll|}
\hline Hostel & $\begin{array}{l}\text { No. of } \\
\text { Students }(\mathbf{n})\end{array}$ & $\begin{array}{l}\text { Sanitary } \\
\text { Workers }\end{array}$ & $\begin{array}{l}\text { no. of } \\
\text { students(n)/sanitary } \\
\text { worker }\end{array}$ & $\begin{array}{l}\text { Total No. of } \\
\text { Dustbins }\end{array}$ & $\begin{array}{l}\text { no. of students } \\
\text { (n)/dustbin }\end{array}$ \\
\hline H1 & 153 & 3 & 51 & 16 & 10 \\
\hline H2 & 29 & 2 & $15^{\star}$ & 8 & 4 \\
\hline H3 & 123 & 5 & $25^{\star}$ & 11 & 11 \\
\hline H4 & 135 & 3 & 45 & 16 & 8 \\
\hline H5 & 156 & 3 & 52 & 11 & 14 \\
\hline H6 & 129 & 3 & 43 & 6 & 22 \\
\hline H7 & 30 & 2 & 15 & 2 & 15 \\
\hline
\end{tabular}

*round figure

Table 3 showed H5 hostel have highest number of students $(n=156)$ and there was only one sanitary worker over 52 students and one dustbin has been use by 14 students. Followed by hostel $\mathrm{H} 1, \mathrm{H} 4$ and $\mathrm{H} 6$ have only three sanitary workers over 153, 135 and 129 students and over one sanitary worker 51,45 and 43 students respectively. In hostel $\mathrm{H} 2$ and $\mathrm{H} 7$ there was only 29 and 30 students over two sanitary workers. Therefore over 108 students (average) there were 3 sanitary workers (average) and 10 dustbins (average).

\section{Volume of waste generated in the hostels}

Table 4 showed that large amount of waste generated from all hostels in the university. Both biodegradable and non biodegradable waste generated.

In $\mathrm{H} 1$ there were two blocks; A \&B and total volume waste generation from entire hostel was $75 \mathrm{~kg} /$ day and rate of waste generation was $0.73 \mathrm{~kg} / \mathrm{capita} /$ day. In $\mathrm{H} 2$ there were total 29 students and total volume waste generated from the hostel was $18 \mathrm{~kg} /$ day and rate of waste generation was $0.34 \mathrm{~kg} /$ capita/day. In $\mathbf{H} 3$, there were three floors and on each floor there were three dustbins of $15 \mathrm{~kg}$ capacity and 123 students generated 42 $\mathrm{kg}$ waste per day and $12 \mathrm{~kg}$ volume of waste generated from the mess per day. Total $54 \mathrm{~kg}$ volume of waste generated from the entire hostel that was around $0.34 \mathrm{~kg} /$ capita/day. $\mathrm{H} 4$, maximum volume of waste was generated form ground floor ( $20 \mathrm{~kg} /$ day). Total 135 students generated $44 \mathrm{~kg}$ of waste per day and $15 \mathrm{~kg}$ of waste generated from the mess per day, so 135 students total rate of waste generation was $0.32 \mathrm{~kg} /$ capita/day. H5, having three floors, includes RL (Residential Lab). Total $45 \mathrm{~kg}$ of volume of waste generated from the floors per day. In the mess there were two types of dustbins, one was $15 \mathrm{~kg}$ and another was $35 \mathrm{~kg}$ and total volume of waste generated from the mess was $25 \mathrm{~kg} /$ day. Total waste generated from the hostel was $70 \mathrm{~kg} /$ day and rate of waste generation was $0.28 \mathrm{~kg} / \mathrm{capita} /$ day.

Table 4. Volume of waste generated in the hostels: 


\begin{tabular}{|llllll|}
\hline Hostel & $\begin{array}{l}\text { No. of } \\
\text { students }\end{array}$ & $\begin{array}{l}\text { No. of } \\
\text { dustbins }\end{array}$ & $\begin{array}{l}\text { Total estimated waste generated } \\
\text { (students + mess) }(\mathrm{kg} / \text { day) }\end{array}$ & $\begin{array}{l}\text { Waste } \\
\text { generation rate } \\
\text { (kg/capita/day) }\end{array}$ & $\begin{array}{l}\text { Waste } \\
\text { collection rate } \\
\text { (kg/bin) }\end{array}$ \\
\hline H1 & 153 & 16 & 75 & 0.73 & 4.68 \\
\hline H2 & 29 & 8 & 18 & 0.34 & 2.50 \\
\hline H3 & 123 & 11 & 54 & 0.34 & 4.90 \\
\hline H4 & 135 & 16 & 59 & 0.32 & 3.68 \\
\hline H5 & 156 & 11 & 70 & 0.28 & 6.36 \\
\hline H6 & 129 & 6 & 51 & 0.24 & 8.50 \\
\hline H7 & 30 & 2 & 16 & 0.33 & 8.00 \\
\hline
\end{tabular}

H6, having three floors, includes RL (Residential Lab). Total $31 \mathrm{~kg}$ of waste generated from the floors per day. In the mess there were two types of dustbins, one was $15 \mathrm{~kg}$ and another was $35 \mathrm{~kg}$ and total waste generated from the mess was $20 \mathrm{~kg} /$ day. Total waste generated from the entire hostel was $51 \mathrm{~kg} /$ day and rate of waste generation was $0.24 \mathrm{~kg} / \mathrm{capita} /$ day. In $\mathbf{H 7}$, total 30 students. Hostel had a garbage window for waste disposal. Total estimated waste generated from the hostel was $10 \mathrm{~kg}$ per day (excluding first and second floor residence) and $6 \mathrm{~kg}$ of waste generated from the mess per day, total waste generation rate was calculated $0.33 \mathrm{~kg} / \mathrm{capita} /$ day. Table 4 further shows the waste collection rate that in $\mathrm{H} 6$ waste collection rate was highest i.e. $8.50 \mathrm{~kg} / \mathrm{bin}$ followed by H5 (6.36 kg/bin) H3 (4.90kg/bin), H1 (4.68 kg/bin), H4 (3.68 kg/bin) and H2 (2.5 $\mathrm{kg} / \mathrm{bin})$.

\section{Pearson correlation coefficient (r) among variables:}

\begin{tabular}{|llllll|}
\hline Variables & $\begin{array}{l}\text { No. of } \\
\text { students }\end{array}$ & $\begin{array}{l}\text { No. of } \\
\text { dustbins }\end{array}$ & $\begin{array}{l}\text { Total estimated waste } \\
\text { generated (kg/day) }\end{array}$ & $\begin{array}{l}\text { Waste } \\
\text { generation rate } \\
\text { (kg/capita/day) }\end{array}$ & $\begin{array}{l}\text { Waste } \\
\text { collection rate } \\
\text { (kg/bin) }\end{array}$ \\
\hline $\begin{array}{l}\text { No. of } \\
\text { students }\end{array}$ & 1 & $0.71^{\star \star}$ & $0.98^{\star \star}$ & 0.24 & 0.07 \\
\hline $\begin{array}{l}\text { No. of } \\
\text { dustbins }\end{array}$ & 1 & $0.78^{\star *}$ & 0.52 & -0.61 \\
\hline $\begin{array}{l}\text { Total waste } \\
\text { generation }\end{array}$ & 1 & 0.38 & -0.03 \\
$\begin{array}{l}\text { Waste } \\
\text { generation } \\
\text { rate }\end{array}$ & & & 1 & -0.31 \\
\hline $\begin{array}{l}\text { Waste } \\
\text { collection rate }\end{array}$ & & & & 1 \\
\hline
\end{tabular}

** Correlation is significant at the 0.01 level, ${ }^{*}$ Correlation is significant at the 0.05 level, 
Table 5 showed the correlation among the different variables, is the statistical analysis index that measures the linear correlation between variables. The value 0.00 to 0.30 (0.00 to -0.30$)$ have negligible correlation, 0.30 to 0.50 ( -0.30 to -0.50 ) have Low positive (negative) correlation, 0.50 to 0.70 ( -0.50 to -0.70 ) have Moderate positive (negative) correlation, 0.70 to 0.90 (-0.70 to -0.90) have High positive (negative) correlation and High positive (negative) correlation have Very high positive (negative) correlation (Hinkle, Wiersma, and Jurs. 2003).

In the present study, available number of dustbins having high positive relation with number of students residing in the hostels $(r=0.71)$ and total waste generated by the students $(r=0.78)$ but moderate negative relation with waste collection rate $(r=-0.61)$. Total estimated waste generation have very high positive relation $(r=0.98)$ with total number of students residing in the hostels but negligible relation with waste collection rate $(r=0.07)$. Waste collection rate have low negative relation $(r=-0.31)$ with waste generation rate.

\section{Summary}

Studies carried in the girl's hostels of CCSHAU premises have shown the current waste management practice from the point of view of solid waste management operators and sanitary workers who are usually involved with biodegradable and non-biodegradable waste. Paper, snakes wrapper, polyethen and sanitary napkin waste were generated in large amount, similar results found in the study by Coke etal. (2016).

Based on the study table 2.1.1 to 2.1.7 showed the volume waste generation by the students on the different floor of the hostels. It revealed that in the hostel $\mathrm{H} 1$ per day generate 75 kilograms of biodegradable and non biodegradable waste which is highest among all girl hostels followed by H5 (70 kg), H4 (59kg), H3 (54 kg), H6 $(51 \mathrm{~kg}), \mathrm{H} 2(18 \mathrm{~kg})$ and $\mathrm{H} 7(16 \mathrm{~kg})$. Waste generation ranges between 0.24 to $0.73 \mathrm{~kg} / \mathrm{capita} /$ day and waste collection rate ranging between 2.50 to $8.50 \mathrm{~kg} / \mathrm{bin}$, were recorded this is similar to the waste generation rates developed by Ogwueleka et al,(2009) which ranged between 0.44 and $0.66 \mathrm{~kg} / \mathrm{capita} /$ day. Where waste generating rate $(\mathrm{kg} /$ capita/day) was highest in hostel $\mathrm{H} 1(0.73)$ with waste collection rate 4.68 (kg/bin) and lowest in hostel $\mathrm{H6}(0.24)$ with highest waste collection rate $8.50 \mathrm{~kg} / \mathrm{bin}$. In the present study correlation showed both positive and negative relation among the variables. Correlation showed the positive relation among total waste generation (kg/day) and number of students, but waste collection rate ( $\mathrm{kg} / \mathrm{bin}$ ) have negative and negligible correlation among waste generation rate and number of students residing in the hostels. Therefore study can conclude that waste generation rate was high but waste collection rate was very low because of the improper ratio $(36: 1)$ between total number of students and sanitary worker. There was no segregation of waste by students, which created difficult situation in front of the sanitary workers. No provision of separate disposal of sanitary napkins.

\section{Conclusions}

Waste management system in the university girl's hostels requires not only an estimation of the solid waste but also an understanding of the students' habits and behaviour towards managing solid waste. Less number of sanitary workers was the major issue with low waste collection rate and no segregation of waste was one of the problems. This practise not only harmful for the students but also for the atmosphere of the university.

\section{Suggestions:}


Based on the findings, this paper proposed few recommendations:

1. Segregation of biodegradable and non biodegradable waste. For that at least two type of dustbin install in each and every floor. Dustbin should be differentiate by green and blue colour (biodegradable and non biodegradable).

2. The entire dustbin covered with disposable polyethenes. If dustbin covered with polyethene, it will be easy for the sanitary workers to clean the dustbin.

3. The university authority should also provide training for its staff and students on various waste management programs so that they can become custodians of the environment. Once the good waste management practices are institutionalized, it will definitely trickle down to the society.

4. Better utilisation of food waste. There are three ways of utilization of waste food. (a) First one is to feed the animals especially swine with this food (b) Second option available is composting of waste food and (c) last but very important alternative available is biogas production. Biogas production is an attractive mean to recycle waste food because it produces gaseous product with methane as the main constituent along with solid residue which can be used as manure similar to that of compost manure. Gaseous product produced from biogas plant can be used as cooking gas. Moreover, this gas can also be used as fuel in generation of electricity and thus, methane is not emitted in the environment thus, alleviating its greenhouse effect. However, during composting methane is generated and released into the environment and that is why biogas production is more beneficial than composting.

5. For the better ways of disposal of sanitary napkins incinerators must installed in every girls hostel, as per the number of the students.

6. Landfill should not treat with chemical for the disposal of the waste. Use of chemical may react with hazardous material and may generate hazardous gases.

\section{Declarations}

I declare that the work in this manuscript is original and is the result of my own work. This manuscript has not been submitted to any other journal for review/publication.

Ethics approval and consent to participate: "Not applicable"

Consent for publication: "Not applicable”

Availability of data and material: The data underlying the findings of this study are available within the article and its supplementary materials without any restrictions. All data included within the manuscript.

Competing interests: "The authors declare that they have no competing interests".

Funding: No funding received by any funding agency.

Authors' contributions: EK collected analyzed and interpreted the data. MM checked and finalized the data. SG formulate objective and check the data. All authors read and approved the final manuscript".

Acknowledgements: "Not applicable"

Page $11 / 12$ 


\section{References}

1. Arora, L., \& Agarwal, S. Knowledge, attitude and practices regarding waste management in selected hostel students of university of Rajasthan, Jaipur. Int J Chem Environ Pharm Res, 2011, 2(1), 40-43.

2. Burnett, G. Overcrowding in Urban Schools. ERIC/CUE Digest Number 107, 1995.

3. CalRecycle. Estimated Solid Waste Generation Rates. 2019. https://www2.calrecycle.ca.gov/WasteCharacterization/General/Rates. Accessed 8 April 2021

4. Cheremisinoff, N.P. Glossary of environmental and waste management terms. Handbook of Solid Waste Management and Waste Minimization Technologies. Butterworth-Heinemann, 2003.337-465.

5. Coker, A. O., Achi, C. G., Sridhar, M. K. C., \& Donnett, C. J. Solid waste management practices at a private institution of higher learning in nigeria. Procedia Environmental Sciences, 2016, 35, 28-39.

6. Davidson, G. Waste management practices: Literature review. Dalhousie University, Office of Sustainability, 2011, 1-59.

7. Earthwatch.2007.Environmental Carer. Earthwatch Nigerian Magzine for Environment \& Development,Port Harcourt,Nigeria. Environmetal Matter (2005) Annual Review World Bank. Washington D.C.

8. Ehrampoush, M. H., \& Moghadam, M. B.Survey of knowledge, attitude and practice of Yazd University of Medical Sciences students about solid wastes disposal and recycling. Journal of Environmental Health Science \& Engineering, 2005,2(2), 26-30.

9. Environment Glossary. United Nations Statistics Division - Environment Statistics. 2016. https://unstats.un.org/unsd/environmentgl/gesform.asp?getitem=1178. Accessed7 June 2020

10. Ishak, N. R., Mahayuddin, S. A., \& Mohamed, M. R. Generation and composition of solid waste in university campus. In Proceedings of the Colloquium on Administrative Science and Technology, 2015,119-126, Springer, Singapore.

11. Ikelegbe, O. O., \& Ogeah, F. N. Sanitation among students on campus. A Multidisciplinary Journal National Association for the advancement of knowledge, 2010, 15(1).

12. Ogwueleka, T. Municipal solid waste characteristics and management in Nigeria. Journal of Environmental Health Science \& Engineering, 2009, 6(3), 173-180.

13. The World Bank. Solid Waste Management. 2019. https://www.worldbank.org/en/topic/urbandevelopment/brief/solid-waste-management. Accessed 4 April 2021 